\title{
Antimicrobial activity of bacterial endophytes from Chirata (Swertia chirata Wall.) and Datura (Datura stramonium L.)
}

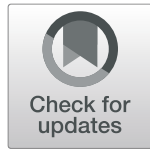

\author{
Rimashree Devi ${ }^{1}$, Tankeswar Nath ${ }^{2 *}$ (D), Rashmi Rekha Boruah², Bishya Darphang ${ }^{2}$, Pranab Kumar Nath², \\ Priyanka Das ${ }^{3}$ and Bidyut Kumar Sarmah ${ }^{2}$
}

\begin{abstract}
Background: Exploration of biocides in microbial system becomes increasingly interesting. Among the different microbial systems, the study of endophytes becomes an important field of research because of their agricultural as well as pharmaceutical importance. Bacterial endophytes from two medicinal plants from North Easter states of India had been studied for their potential antibacterial and antifungal properties.

Results: Bacterial endophytes from two medicinal plant species abundantly available in North Eastern states of India, Chirata (Swertia chirata) and Datura (Datura stramonium), had been isolated and studied for their anti-bacterial and anti-fungal activities. Six bacterial endophytes were isolated from Chirata and 5 from Datura. All these bacterial isolates were initially isolated by observing their colony morphology, and then 9 morphologically distinct bacterial isolates were identified at molecular level by their 16s rRNA sequencing. Among the identified isolates, 5 were found to be belonged to genus Staphylococcus, 2 Bacillus, and one each belonged to Rhodococcus and Cupriavidus. Antibacterial study was carried out against 2 plant pathogenic bacteria, viz., Xanthomonas oryzae and Ralstonia solanacearum. Antifungal study was carried out against 2 plant pathogenic fungi, viz., Fusarium oxysporum and $F$. solani. Out of 6 bacterial isolates from Chirata, one showed antibacterial as well as antifungal properties, and another one showed antifungal properties only. Likewise, out of 5 bacterial isolates from Datura, one found to have both antibacterial and antifungal properties, and another one has only antifungal properties.

Conclusion: Few bacterial endophytes isolated from S. chirata and D. stramonium L., abundantly available in North Eastern part of India, had potential antibacterial as well as antifungal properties. This could be considered as the baseline information on potential antibacterial and antifungal agents from bacterial endophytes. Further investigations are required to assess their efficacy against several other bacterial and fungal diseases of economic importance.
\end{abstract}

Keywords: Endophytes, Swertia chirata, Datura stramonium, Antimicrobial activity

\section{Background}

A broad range of synthetic agents are widely used to balance the economic losses caused by pathogens in agriculture. Due to their effect on nature and the health risks, their application on a broader scale has been phasing out (Kim et al. 2017). Recently, there has been an

\footnotetext{
* Correspondence: tankeswar@yahoo.com

${ }^{2}$ DBT-AAU Centre, Assam Agricultural University, Jorhat-13, India

Full list of author information is available at the end of the article
}

emerging attempt to explore nature-friendly compounds, which could substitute for chemically synthesized products. It is found that microorganisms associated with plants (endophytes) rather than plants themselves have proved to offer material and products with superior therapeutic potential (Guo et al. 2008). Endophytes are an increasingly important area of research in many fields because of their chemical diversity and their ability to produce many novel secondary metabolites that can be 
utilized for fuel, medicine, and agriculture. It is their chemical diversity that sparks profound interest in these microorganisms. Some of the antimicrobial compounds produced by endophytic microbes have the effectiveness against pathogens, which have developed resistances to antibiotics. Several strains from the Ascomycota pestalotiopsis have been shown to have a broad range of antimicrobial effects, even against methicillin-resistant Staphylococcus aureus (Rai et al. 2014). Many endophytes are members of common soil bacterial genera, such as Pseudomonas, Burkholderia, and Bacillus (Lodewyckx et al. 2002). These genera are well known for their diverse range of secondary metabolic products including antibiotics, anticancer compounds, volatile organic compounds, antifungal, antiviral, insecticidal, and immunosuppressant agents. While most of the research has been focused on fungal based production of antimicrobial products, a number of low-molecularweight compounds found to be active at low concentrations against a range of human, animal, and plant pathogenic bacteria have been isolated from bacterial endophytes. One member of the plant-associated fluorescent pseudomonads, $P$. viridiflava, which was isolated on and within the tissues of many grass species (Miller et al. 1998) was found to produce 2 novel antimicrobial compounds called ecomycins.

Despite the many known benefits conferred by endophytes, conventional agricultural practices continue to take priority. Current agriculture relies heavily on fungicides and high levels of chemical fertilizers. The use of fungicides has a negative effect on endophytic fungi, and the used fertilizers reduce a plant's dependence on its endophytic symbiont (Le Cocq et al. 2017). In addition to the aforementioned benefits, the interest in use of bioinsecticides derived from endophytes is a potential area for phase away from inorganic pesticide-based cultivation system. As we have become more aware of the damage that synthetic insecticides cause to the environment, genotoxicity, and harm to beneficial insects, biological insecticides may become more important to the agricultural industry (Strobel, 2003). It has already been established that the endophytes of medicinal plants participate in biochemical pathways and produce analogous or novel bioactive compounds (Zhao et al. 2011). In this study, bacterial endophytes from 2 abundantly available folklore medicinal plant species from North East India, Chirata $(S$. chirata), and Datura (D. stramonium) were tested to explore their antibacterial as well as antifungal properties against few economically important pathogenic bacteria, viz., Xanthomonas oryzae and Ralstonia solanacearum, and fungi, viz., Fusarium oxysporum and F. solani.

\section{Methods}

\section{Sample collection and cultivation}

Seeds of S. chirata and D. stramonium were collected from Gossaigaon, Kokrajhar $\left(26.4371^{\circ} \mathrm{N}, 89.9767^{\circ} \mathrm{E}\right)$, and Bijoynagar, Jorhat $\left(26.7509^{\circ} \mathrm{N}, 94.2037^{\circ} \mathrm{E}\right)$ of Assam, respectively. Subsequently, they were grown in the experimental field for further study.

\section{Isolation of endophytes}

Bacterial endophytes were isolated at flowering stages of both the plant species. After proper surface sterilization as described by Devi et al. (2017), the shoots ( $5 \mathrm{~g}$ ) and roots $(1 \mathrm{~g})$ of the both the plant samples were weighed and grinded using mortar and pestle, separately. The extracts were then centrifuged at $10,000 \mathrm{rpm}$ for $10-20$ min. The aliquots were then spread over nutrient agar plate amended with fungicide, cycloheximide. Nutrient agar plates prepared were incubated at $37{ }^{\circ} \mathrm{C}$ for $24-48$ h. Colonies with different morpho-types were selected and purified for further study.

\section{Mass multiplication of endophytic isolates}

Pure cultures of endophytic bacteria were fermented at shake-flask level in $1 \mathrm{~L}$ Erlenmeyer flasks that contained $600 \mathrm{ml}$ nutrient broth. Bacterial culture for each bacterial isolate was grown at $28{ }^{\circ} \mathrm{C}$ and $200 \mathrm{rpm}$ in a mechanical shaker incubator, and growth curve was drawn to know the best time of harvest for secondary metabolites. The point just after entering the stationary phase was considered the best harvest time.

\section{Molecular analysis of endophytic bacterial isolates}

Genomic DNA isolation was done by using the modified method of Ligozzi and Fontana (2003). Amplification of $16 \mathrm{~S}$ rRNA gene was performed using the $27 \mathrm{~F}$-AGAG TTTGATCCTGGCTCAG forward and 1492 R-GGTT ACCTTGTTACGACTT reverse primers. The PCR was carried out with an initial denaturation at $94{ }^{\circ} \mathrm{C}$ for 2 min, 30 cycles of $94{ }^{\circ} \mathrm{C}$ for $1 \mathrm{~min}, 56^{\circ} \mathrm{C}$ for $1 \mathrm{~min}, 72^{\circ} \mathrm{C}$ for $1 \mathrm{~min}$, and final extension at $72^{\circ} \mathrm{C}$ for $10 \mathrm{~min}$. The amplified products of the isolates were sequenced using 454 automated Pyrosequencer (Agrigenome, Kerala, India). The sequenced $16 \mathrm{~S}$ rRNA genes from both the ends were further pre-processed and assembled to a consensus sequence using Codon Code Aligner version 4.1(Codon Code Corporation, USA).

\section{Phylogenetic analysis of $16 \mathrm{~S}$ rRNA}

Phylogenetic analysis of 16S rRNA gene sequences for each bacterial strain along with their closest relatives was performed using the Kimura 2-parameters method incorporated in MEGA version 5.1 .0 by $\mathrm{NJ}$ method to assign each bacterial isolate in their respective taxonomic position (Tamura et al. 2007). The 16S rRNA gene sequences of the 9 different strains were submitted to GenBank of NCBI through sequence submission tool, Bank. It was where they were assigned GenBank accession numbers. In addition, the strains identified were 
taken together for construction of phylogenetic tree using NJ method incorporated in MEGA.

\section{Culture of plant pathogenic bacteria and fungi}

Two bacterial plant pathogenic species, Xanthomonas oryzae and Ralstonia solanacearum, and two plant pathogenic fungal species, Fusarium oxysporum and $F$. solani, were collected from the Plant Pathology Department of Assam Agricultural University, Jorhat, Assam.

\section{Screening of bacterial endophytes for their antimicrobial activities}

The isolated bacterial endophytes were screened for their antimicrobial activity using agar well diffusion method with few modifications (Schillinger and Lücke, 1989) against plant pathogenic bacteria and with modified dual culture method (Gkarmiri et al. 2015) against fungal plant pathogens. For antimicrobial assay, 3 replications were taken and mean value was reported. The bacterial phytopathogens used were $X$. oryzae and $R$. solanacearum, and the fungal phytopathogens were $F$. oxysporum and $F$. solani. The bacterial endophyte isolates were grown in NA broth for $48 \mathrm{~h}$, at $28^{\circ} \mathrm{C}$ and $200 \mathrm{rpm}$ in a mechanical shaker incubator, and then centrifuged at $10,000 \mathrm{rpm}$ for $10 \mathrm{~min}$. The supernatant obtained was filtered through micro-filter $(0.22 \mu \mathrm{m}$ pore size). The filtrate obtained was used for the determination of antimicrobial activity. To assay antibacterial activity, $500 \mu \mathrm{l}$ of active broth cultures (overnight grown) of phytopathogenic bacteria, X. oryzae, and $R$. solanacearum were transferred to the NA agar Petri plates, separately and spread uniformly with a glass spreader. Four wells with 7-mm diameter were made in each of these plates using sterile gel puncher. Out of the 4, 2 wells were used for test samples, one was used as a positive control, and the other was used as a negative control. An aliquot of $200 \mu \mathrm{l}$ of the sample was loaded into the wells of the plates. In the case of positive control, instead of the sample, $200 \mu \mathrm{l}$ streptomycin was used $(50 \mu \mathrm{g} / \mathrm{ml})$, and in the negative control, the same amount of sterile water was used. All the plates were then kept in incubation at $30 \pm 2{ }^{\circ} \mathrm{C}$. After $24 \mathrm{~h}$ of incubation, plates were observed for formation of clear zone of inhibition around the well and measured. To evaluate antifungal activity, a loop-full of active fungal culture was placed on one edge of the sterile plates containing PDA media. One well with 7 -mm diameter was made in the center of the plate using sterile gel puncher. An aliquot of $200 \mu \mathrm{l}$ of the sample was loaded into the well of the plate. In place of test sample, $200 \mu \mathrm{l}$ cycloheximide $(50 \mu \mathrm{g} / \mathrm{ml})$ was used in the positive control and the same amount of sterile water was used in the negative control. Plates were then incubated at $30 \pm 2$ ${ }^{\circ} \mathrm{C}$ and observed for formation of zones of inhibition every $24 \mathrm{~h}$ for 6 days.

\section{Results}

Isolation of endophytes from the plant samples

In the present study, a total of 11 endophytic bacterial isolates was isolated, 6 from Chirata and 5 from Datura at their flowering stages, and studied for their antimicrobial activity. Out of the 6 bacterial isolates obtained from Chirata, 2 were from roots, coded as CS1 and CS2, and 4 were from shoots coded as CS3, CS4, CS5, and CS6. The rest 5 bacterial endophytes were isolated from $\mathrm{Da}$ tura. Among the 5 bacterial endophytes, 3 were from shoots, coded as DS1, DS2, and DS3, and 2 were from roots, coded as DS4 and DS5. Colony morphology, especially the shape and color of the colonies of all the bacterial isolates, was studied. Some bacterial colonies were found to be white, round, and smooth, while some others were creamy white and circular (Table 1). In both plant systems, more numbers of bacterial endophytes were found in shoots than in roots.

\section{Identification of the endophytic isolates}

Analysis of total base nucleotide of $16 \mathrm{~S}$ rRNA gene sequences was done by multiple alignments using neighborjoining method of MEGA 6 tool with 1000 bootstrap value. From the BLAST analysis of the sequence reads, the nine isolates were found to be from four different groups based on sequences similarities (Fig. 1).

Out of the 9 sequenced isolates, 5 were identified as belonging to Staphylococcus species (98\% identity), 2 to $\mathrm{Ba}$ cillus species (99\% identity), one to Rhodococcus, and the rest one showed similarity with Cupriavidas as highly similar sequences tend to lie in the same group (Table 2).

In the present study, the Staphylococcus spp. were placed in 2 different groups, which indicated that they belong to the same species, but may be different in strain level. Similarly, B. mycoides and B. subtilis were placed at the same group, due to their sequence similarities. The isolates $R$. jialingiae and $C$. metalidurans were

Table 1 Morphological characterization of isolated endophytic bacteria

\begin{tabular}{lll}
\hline Code no. & Source of isolation & Colony morphology \\
\hline CS1 & Chirata, root & Whitish, circular \\
CS2 & Chirata, root & Irregular, creamy white \\
CS3 & Chirata, shoot & Large colonies, opaque, round \\
CS4 & Chirata, shoot & Curled, round \\
CS5 & Chirata, shoot & Small colonies, round \\
CS6 & Chirata, shoot & Irregular, creamy, opaque \\
DS1 & Datura, shoot & Yellowish in color, opaque \\
DS2 & Datura, shoot & Very small colonies, transparent \\
DS3 & Datura, shoot & Yellowish, circular \\
DS4 & Datura, root & Creamish, irregular in shape \\
DS5 & Datura, root & Small, circular \\
\hline
\end{tabular}




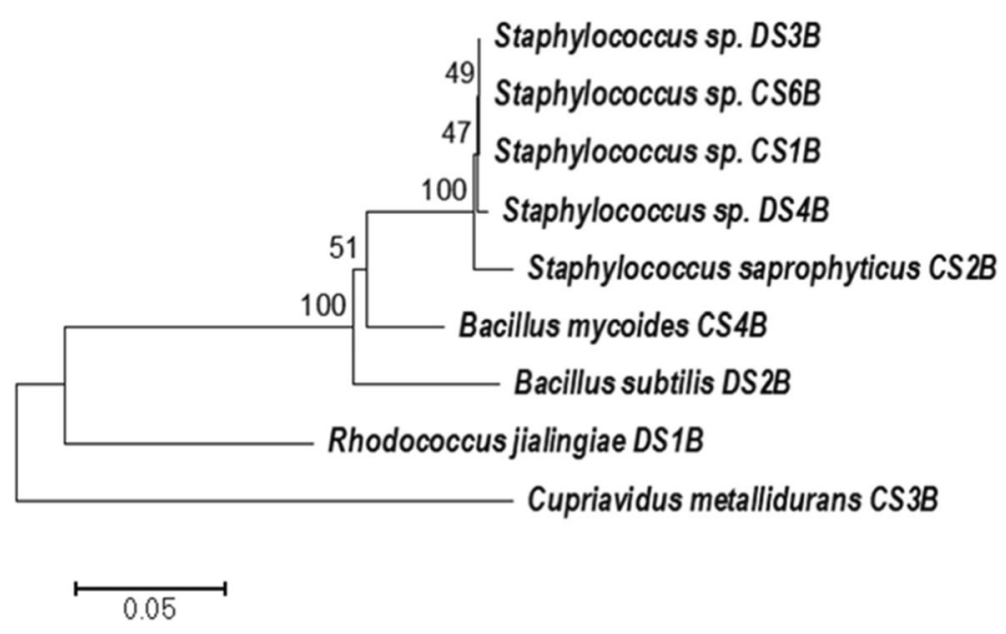

Fig. 1 Phylogenetic tree based on 16S rRNA sequences of endophytic bacteria

distantly related to the genera Staphylococcus and Bacillus and were placed in different groups (Fig. 1).

\section{Anti-bacterial activity of bacterial endophytes}

In this study, the antibacterial activity of bacterial endophytes against 2 plant pathogenic-bacterial species, i.e., $X$. oryzae and $R$. solanacearum, was evaluated. Antibacterial activity of the bacterial isolates was investigated by agar well diffusion method. Among the 6 bacterial isolates, isolated from Chirata, the CS1 (Staphylococcus sp.) and the CS4 (Bacillus sp.) inhibited the growth of X. oryzae and R. solanacearum, respectively (Fig. 2a, b). Similarly, the 2 bacterial isolates from Datura, the DS5 (unidentified) and the DS1 (Rhodococcus jialingiae), showed antibacterial activity against $X$. oryzae and $R$. solanacearum, respectively (Fig. 2c, d).

\section{Antifungal activity of bacterial endophytes}

In this study, the antifungal activity of bacterial endophytes was evaluated against 2 plant pathogenic-fungal species, i.e., F. oxysporum and F. solani. Antifungal activity of the bacterial isolates was investigated by modified dual culture method. Among the 6 bacterial isolates from Chirata, only CS1 (Staphylococcus sp.) inhibited the growth of F. oxysporum (Fig. 3a). Similarly, only one bacterial isolate from Datura, DS5 (unidentified), showed antifungal against $F$. solani (Fig. 3b).

\section{Discussion}

The objective of the present investigation was to isolate and evaluate the antibacterial activities of endophytic bacteria from 2 important medicinal plants species, Chirata (S. chirata) and Datura (D. stramonium). All total of 11 bacterial endophytes were isolated from the shoots and roots of both plant species at their flowering stages, and their morphological as well as molecular characterization were carried out. In both the plant systems, more numbers of bacterial endophytes were found in shoots as compared to roots, which indicated that shoots may provide more favorable environment to endophytic bacteria than root. Flowering stage was considered because, reportedly, the root rhizospheric endophytes entered into the plant at vegetative stage, and their population is going to be increased and get

Table 2 Nucleotide nBLAST results of the endophytic isolates

\begin{tabular}{lllll}
\hline SI. no. & Sample & Result & Identification (\%) & Accession no. \\
\hline 1. & CS1 & Staphylococcus sp. & 98 & KT922162 \\
2. & CS2 & S. saprophyticus & 98 & KT922167 \\
3. & CS3 & Cupriavidus metallidurans & 96 & MH348792 \\
4. & CS4 & Bacillus mycoides & 99 & MG205997 \\
5. & CS6 & Staphylococcus sp. & 98 & MK120439 \\
6. & DS1 & Rhodococcus jialingiae & 98 & LT160790 \\
7. & DS2 & B. subtilis & 99 & KM008606 \\
8. & DS3 & Staphylococcus sp. & 99 & MK256328 \\
9. & DS4 & Staphylococcus $s p$. & 97 & MK256328 \\
\hline
\end{tabular}



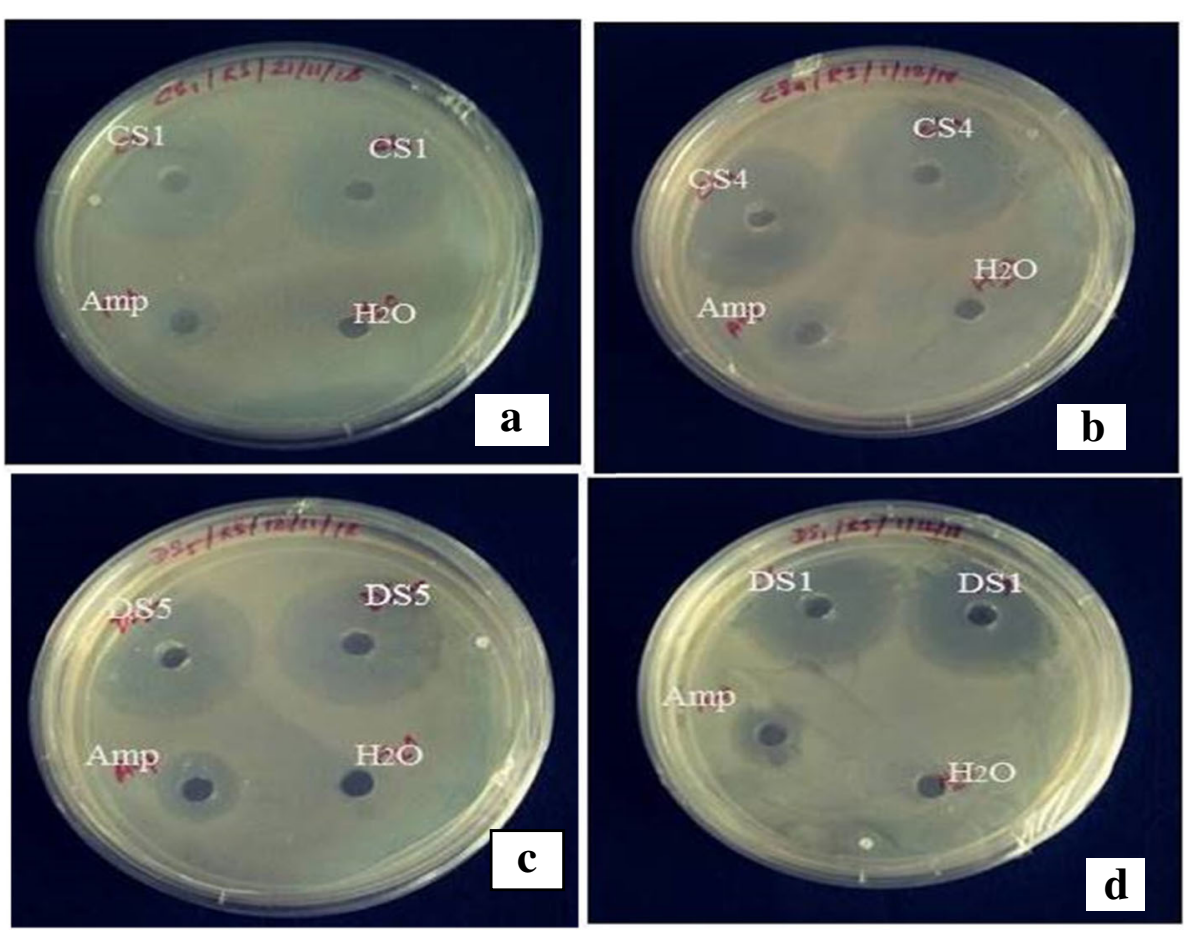

Fig. 2 Agar well diffusion assay of bacterial endophytes against plant pathogenic bacteria. a CS1 isolated from Chirata against bacterial pathogen (X. oryzae). b CS4 isolated from Chirata against bacterial pathogen ( $R$. solanacearum). c DS5 isolated from Datura against bacterial pathogen $(X$. oryzae). d DS1 isolated from Datura against bacterial pathogen (R. solanacearum)

maximum number at flowering stage, and again started declined at maturity stage, partially due to factors like nutrient deficiency, water stress, and free radical formation (Marag and Suman 2018). Colony morphology, especially the shape and color of the colonies of all the bacterial isolates, was studied. Some bacterial colonies were found to be white, round, and smooth, while some colonies were creamy white and circular, which indicated their morphological diversities. From the molecular characterization results, a high species-specific homogeneity was observed when $16 \mathrm{~S}$ rRNA from different strains and different species were compared. Most of the sequenced isolates were identified as Staphylococcus species while; few of them identified as Bacillus Rhodococcus and Cupriavidas species. A similar study was undertaken by Bredow et al. (2015) on in silico analysis of $16 \mathrm{~S}$ rRNA gene of endophytic bacteria isolated from the aerial parts and seeds of agricultural crops, and most of the isolates they isolated were identified to be genus, Bacillus. Another study was carried out by Liaqat and
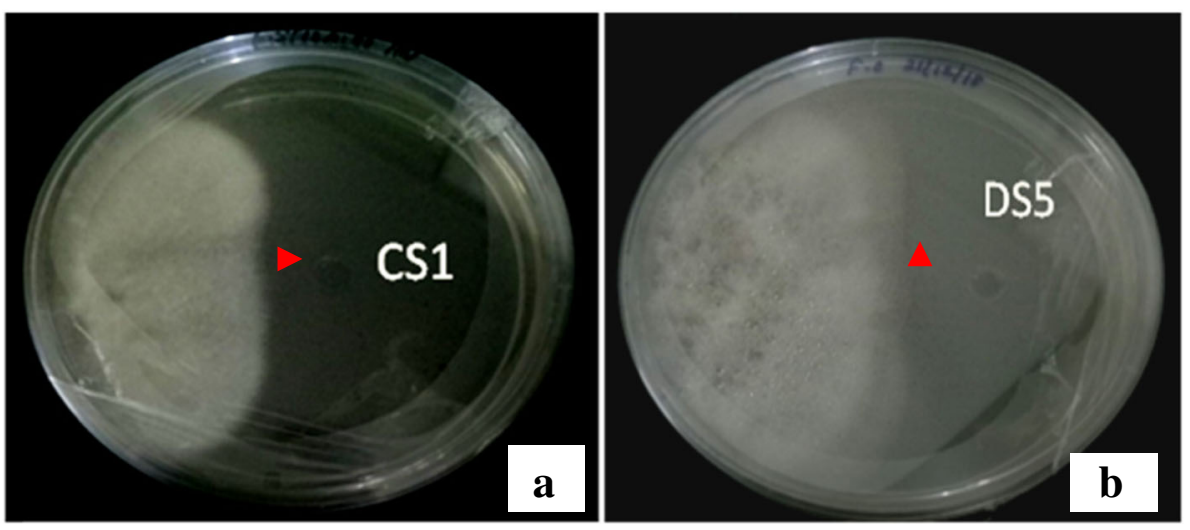

Fig. 3 Dual culture assay of antifungal activity of bacterial endophytes (arrows indicate wells). a CS1 isolated from Chirata against fungal pathogen (F. oxysporum). b DS5 isolated from Datura against fungal pathogen (F. solani) 
Eltem (2016) on identification and characterization of endophytic bacteria isolated from in vitro cultures of peach and pear rootstocks, and they reported that most of isolates were belonged to the genus, Staphylococcus. Although the 16S rRNA sequenced analysis was considered very good at identifying microorganisms at genus and species level, however, it was unable to differentiate at the sub species and strain level, and was therefore not an appropriate method to measure intra-species relationships (Stackebrandt and Goebel 1994). However, a large number of endophyte has been reported to be remaining unidentified due to their uncultivable nature (Schulz and Boyle 2005).

Isolated bacterial endophytes were finally screened for their antibacterial as well as antifungal activities, against few plant pathogenic bacteria and fungi, separately. Their antibacterial activity was studied against $X$. oryzae and $R$. solanacearum by agar well diffusion method. Out of the 11 bacterial isolates, only 2 bacteria isolates viz., CS1 (Staphylococcus sp.) and DS5 (unidentified), showed antibacterial activity against $X$. oryzae, while another 2 bacterial isolates viz., CS4 (Bacillus sp.) and DS1 (Rhodococcus jialingiae), showed antibacterial activity against $R$. solanacearum. The antifungal activity of bacterial endophytes was evaluated against 2 plant pathogenic-fungal species, i.e., F. oxysporum and F. solani, by modified dual culture method. Out of the 11 bacterial isolate, only 2 isolates showed antifungal activity. One isolate, CS1 (Staphylococcus sp.) showed antifungal activity against $F$. oxysporum, and the other, DS5 (unidentified) showed antifungal against $F$. solani. From both antibacterial and antifungal study, it was observed that the isolate, CS1 (Staphylococcus sp.) and DS5 (unidentified), had both antibacterial as well as antifungal properties. So, the results indicated the strain-specific nature of the endophytic bacterial isolates for their antimicrobial activity against these 4 plant pathogens. The endophytic bacterial isolates showing antimicrobial activity might have the metabolite(s) having antibiotic properties. Chen et al. (2019) isolated Bacillus endophyte from peanut root and showed that it produced antimicrobial compounds with inhibitory effects against Aspergillus flavus and $R$. solanacearum. In another study, Morare et al. (2018) isolated bacterial endophytes from the traditional medicinal plant Crinum macowanii Baker belonging to genera Staphylococcus, Bacillus, and Acinetobacter exhibited antibacterial activity against 5 bacterial pathogens viz., Escherichia coli, P. aeruginosa, Klebsiella pneumoniae, S. aureus, and B. cereus. Beiranvand et al. (2017) also reported that bacterial endophytes isolated from medicinal plants exhibited antimicrobial activity against some bacterial pathogens. Similar research works had been reported where endophytic microbial strains were isolated from medicinal plants and assayed for antimicrobial activities (Khan et al. 2017).

\section{Conclusion}

From this study, it was found that the bacterial endophytes isolated from the 2 medicinal plants, S. chirata and $D$. stramonium, could suppress the growth of bacterial as well as fungal phytopathogens. In order to understand the symbiotic role of these endophytes in the host plants, further studies are necessary to identify the active compounds produced by them inside the host systems, using analytical chemistry. Such compounds can be used against fungal phytopathogens as biocontrol agents.

\section{Abbreviations}

NJ: Neighbor joining; MEGA: Molecular evolutionary genetics analysis; NA: Nutrient agar; PDA: Potato dextrose agar

\section{Acknowledgements}

The authors are thankful to DBT-AAU Centre and Department of Agricultural Biotechnology, Assam Agricultural University, Jorhat, Assam, for providing with the workspace and facility to carry out the research.

\section{Authors' contributions}

All authors contributed to this research and preparation of manuscript. TN, $\mathrm{BKS}$, and RD conceptualized and designed this research. The research was carried out by $\mathrm{RD}$. TN, RD, and RRB analyzed the data and result. RD drafted the first version of the manuscript. RD, TN, RR B, BD' PKN, and PD revised and finalized the manuscript. All authors read and approved the final manuscript.

\section{Funding}

This is part of post-graduate research work and fund required for carrying out this research given by the Assam Agricultural University, Jorhat, India.

\section{Declarations}

Ethics approval and consent to participate Not applicable

\section{Consent for publication}

Not applicable

\section{Competing interests}

The authors declare that they have no competing interests.

\section{Author details}

${ }^{1}$ Department of Agricultural Biotechnology, Assam Agricultural University, Jorhat-13, Assam, India. 'DBT-AAU Centre, Assam Agricultural University, Jorhat-13, India. ${ }^{3}$ Department of Biochemistry and Agricultural Chemistry, Assam Agricultural University, Jorhat-13, India.

Received: 1 December 2020 Accepted: 6 April 2021

Published online: 20 April 2021

\section{References}

Beiranvand M, Amin M, Hashemi-Shahraki A, Romani B, Yaghoubi S, Sadeghi P (2017) Antimicrobial activity of endophytic bacterial populations isolated from medical plants of Iran. Iran J Microbiol 9(1):11-18

Bredow C, Azevedo JL, Pamphile JA, Mangolin CA, Rhoden SA (2015) In silico analysis of the $16 \mathrm{~S}$ rRNA gene of endophytic bacteria, isolated from the aerial parts and seeds of important agricultural crops. Genet Mol Res 14(3): 9703-9721. https://doi.org/10.4238/2015.August.19.3

Chen L, Shi H, Heng J, Wang D, Bian K (2019) Antimicrobial, plant growthpromoting and genomic properties of the peanut endophyte Bacillus velezensis LDO2. Microbiol Res 218:41-48. https://doi.org/10.1016/j.micres.201 8.10 .002

Devi K, Gogoi MB, Singh S, Sarmah B, Modi MK, Sen P (2017) In vitro regeneration of banana and assessment of genetic fidelity in the regenerated plantlets through RAPD. Annu Res Rev 17(6):1-11 
Gkarmiri K, Finlay RD, Alström S, Thomas E, Cubeta MA, Högberg N (2015) Transcriptomic changes in the plant pathogenic fungus Rhizoctonia solani AG-3 in response to the antagonistic bacteria Serratia proteamaculans and Serratia plymuthica. BMC Genom 16(1):630-646. https://doi.org/10.1186/s12 864-015-1758-z

Guo B, Wang Y, Sun X, Tang K (2008) Bioactive natural products from endophytes: a review. Appl Biochem Microbiol 44(2):136-142. https://doi. org/10.1134/S0003683808020026

Khan AL, Gilani SA, Waqas M, Al-Hosni K, Al-Khiziri S, Kim YH, Hussain J (2017) Endophytes from medicinal plants and their potential for producing indole acetic acid, improving seed germination and mitigating oxidative stress. J Zhejiang Univ Sci B 18(2):125-137. https://doi.org/10.1631/jzus.B1500271

Kim KH, Kabir E, Jahan SA (2017) Exposure to pesticides and the associated human health effects. Sci. Total Environ 575:525-535. https://doi.org/10.1016/ j.scitotenv.2016.09.009

Le Cocq K, Gurr SJ, Hirsch PR, Mauchline TH (2017) Exploitation of endophytes for sustainable agricultural intensification. Mol Plant Pathol 18(3):469-473. https://doi.org/10.1111/mpp.12483

Liaqat F, Eltem R (2016) Identification and characterization of endophytic bacteria isolated from in vitro cultures of peach and pear rootstocks. 3 Biotech 6:120127

Ligozzi M, Fontana R (2003) Isolation of total DNA from bacteria and yeast. Afr J Biotechnol 2(8):251-253

Lodewyckx C, Vangronsveld J, Porteous F, Moore ER, Taghavi S, Mezgeay M, der Lelie DV (2002) Endophytic bacteria and their potential applications. Crit Rev Plant Sci 21(6):583-606. https://doi.org/10.1080/0735-260291044377

Marag PS, Suman A (2018) Growth stage and tissue specific colonization of endophytic bacteria having plant growth promoting traits in hybrid and composite maize (Zea mays L.). Microbiol Res 214:101-113. https://doi.org/1 0.1016/j.micres.2018.05.016

Miller CM, Miller RV, Garton-Kenny D, Redgrave B, Sears J, Condron MM, Teplow DB, Strobel GA (1998) Ecomycins, unique antimycotics from Pseudomonas viridiflava. J Appl Microbiol 84(6):937-944. https://doi.org/10.1046/j.1365-2 672.1998.00415.x

Morare RF, Ubomba-Jaswa E, Serepa-Dlamini MH (2018) Isolation and identification of bacterial endophytes from Crinum macowanii Baker. Afr J Biotechnol 17(33):1040-1047

Rai M, Rathod D, Agarkar G, Dar M, Brestic M, Pastore GM, Junior MR (2014) Fungal growth promoter endophytes: a pragmatic approach towards sustainable food and agriculture. Symbiosis 62(2):63-79. https://doi.org/10.1 007/s13199-014-0273-3

Schillinger U, Lücke FK (1989) Antibacterial activity of Lactobacillus sake isolated from meat. Appl Environ Microbiol 55(8):1901-1906. https://doi.org/10.112 8/AEM.55.8.1901-1906.1989

Schulz B, Boyle C (2005) The endophytic continuum. Mycol Res 109(6):661-686. https://doi.org/10.1017/S095375620500273X

Stackebrandt E, Goebel BM (1994) Taxonomic note: a place for DNA-DNA reassociation and $16 \mathrm{~S}$ rRNA sequence analysis in the present species definition in bacteriology. Int J Syst Evol Microbiol 44(4):846-849. https://doi.org/10.1 099/00207713-44-4-846

Strobel GA (2003) Endophytes as sources of bioactive products. Microbes Infect 5(6):535-544. https://doi.org/10.1016/S1286-4579(03)00073-X

Tamura K, Dudley J, Nei M, Kumar S (2007) MEGA4: molecular evolutionary genetics analysis (MEGA) software version 4.0. Mol Biol Evol 24(8):1596-1599. https://doi.org/10.1093/molbev/msm092

Zhao K, Penttinen P, Guan T, Xiao J, Chen Q, Xu J, Lindström K, Zhang L, Zhang $X$, Strobel GA (2011) The diversity and anti-microbial activity of endophytic actinomycetes isolated from medicinal plants in Panxi plateau, China. Curr Microbiol 62(1):182-190. https://doi.org/10.1007/s00284-010-9685-3

\section{Publisher's Note}

Springer Nature remains neutral with regard to jurisdictional claims in published maps and institutional affiliations.

\section{Submit your manuscript to a SpringerOpen ${ }^{\circ}$ journal and benefit from:}

- Convenient online submission

- Rigorous peer review

- Open access: articles freely available online

- High visibility within the field

- Retaining the copyright to your article

Submit your next manuscript at $\boldsymbol{\nabla}$ springeropen.com 